\title{
Factors affecting the choice of Incoterms: The case of companies operating in Poland
}

\author{
Agnieszka Hajdukiewicz, Bożena Pera
}

\section{A B S T R A C T}

Objective: The main objective of this paper is to identify and examine the main factors which affect the choice of Incoterms ${ }^{\circledR}$ rules that are used in international sales contracts by enterprises operating in Poland.

Research Design \& Methods: Mixed methods research was conducted to achieve this goal. The methods applied include the critical review of existing literature on Incoterms ${ }^{\circledR}$ and their use in international sales contracts and a survey carried out among export/import managers of companies operating in Poland.

Findings: Results of this study proved that there are many external and internal factors to consider in the Incoterms ${ }^{\circledR}$ selection process, which can affect cost, risks, liabilities and formalities of international transactions. The main problem faced by many companies is making incorrect or decisions on Incoterms ${ }^{\circledR}$, as traders often underestimate their potential, misuse or apply certain terms too much, choosing them without much reflection and continuing to use the same Incoterms ${ }^{\circledR}$ even if other conditions of transactions differ significantly. The fact that most of companies don't consider domestic and foreign competition as a factor strongly affecting their decisions on Incoterms ${ }^{\circledR}$ may suggest that the use of Incoterms ${ }^{\circledR}$ as a strategic tool for building competitive advantage is often underestimated. Also, many traders seem to be mainly focused on cost of transportation but do not see the link between Incoterms ${ }^{\circledR}$ and terms of payment or other financial aspects of transaction. The results revealed also that the selection of Incoterms ${ }^{\circledR}$ is often considered as a difficult task because of the insufficient knowledge on the topic and that entrepreneurs point out the need for further training that would increase their knowledge and skills in the proper use of Incoterms ${ }^{\circledR}$.

Implications \& Recommendations: The obtained results can be used both by entrepreneurs making decisions about Incoterms ${ }^{\circledR}$, who need guidance on their correct application. They also give indications for the education sector on how to better respond to the need for expanding knowledge and skills about Incoterms ${ }^{\circledR}$, especially with respect to Incoterms ${ }^{\circledR}$ selection and its determinants, by shaping its educational offer appropriately.

Contribution \& Value Added: The research provides deeper understanding and fills the gap in knowledge regarding Incoterms ${ }^{\circledR}$ and their appropriate use in international trade. It considers different factors affecting decisions on selection of Incoterms ${ }^{\circledR}$ made by companies operating in Poland.

$\begin{array}{ll}\text { Article type: } & \text { research article } \\ \text { Keywords: } & \text { Incoterms; delivery terms; trade terms; sales and purchase contract; trade facilitation } \\ \text { JEL codes: } & \text { F23, K12, M16 }\end{array}$

Received: 15 July $2021 \quad$ Revised: 17 November $2021 \quad$ Accepted: 18 November 2021
\end{abstract}

\section{Suggested citation:}

Hajdukiewicz, A., \& Pera, B. (2021). Factors affecting the choice of Incoterms: The case of companies operating in Poland. International Entrepreneurship Review, 7(4), 35-50. https://doi.org/10.15678/IER.2021.0704.03

\section{INTRODUCTION}

One of the main clauses in international contracts of sale is the trade term. To prevent problems arising from different interpretations of trade terms in various countries, industries and sectors, it is recommended that all sales contracts should include reference to the International Commercial Terms (Incoterms $\left.^{\circledR}\right)$, which are a set of the globally-accepted commercial terms issued by the International Chamber of Commerce (ICC). They provide harmonized rules for the interpretation of the most fre- 
quently used terms for the delivery of product in international sales transactions. Nowadays Incoterms ${ }^{\circledR}$ are usually incorporated in international business contracts but it is crucial that traders apply a trade term that is proper for their business transaction. There are many factors to consider in the Incoterms ${ }^{\circledR}$ selection process, which can affect cost, risks, obligations and formalities of international transactions. In practice, many companies, particularly SME's, encounter difficulties in the correct application of Incoterms $s^{\circledR}$ and make wrong decision regarding Incoterms ${ }^{\circledR}$. They underestimate their potential, misuse or apply certain terms too much. This may negatively affect the profitability of the transaction and in some cases even cause serious losses for a company.

The selection of Incoterms ${ }^{\circledR}$ is often considered as a difficult task because of the insufficient knowledge in this field. Additionally, old trading practices do not fully match modern transport requirements, increasing risks for traders and creating even bigger challenges for the correct application of Incoterms $s^{\circledR}$. This study endeavors to increase the knowledge and understanding of the topic that in our opinion has a great importance for business, because properly used Incoterms ${ }^{\circledR} 2020$ can be an effective management tool. We also found out with surprise that the number of the scientific publications on this subject is limited and the significance of Incoterms ${ }^{\circledR}$ is often underestimated not only among business practitioners but also among researchers.

The main aim of this paper is to identify and examine the main factors which affect the choice of Incoterms ${ }^{\circledR}$ rules that are used in international sales contracts by enterprises operating in Poland.

By an in-depth literature review and a survey conducted among companies involved in foreign trade, the main selection criteria that might be applied to choose the right Incoterm rule are identified and discussed.

The structure of this paper is as follows: first, a literature review gives an overview of Incoterms ${ }^{\circledR}$ 2020 and issues related to their application in international contracts of sale and is followed by an identification of potential selection criteria. Then, the analysis of various aspects of decision making on Incoterms ${ }^{\circledast} 2020$, including the actual choice criteria, in sample companies is conducted, followed by the discussion on the effective use of Incoterms ${ }^{\circledR}$ in international sales contracts and the formulation of some recommendation for decision-makers based on conclusions of the research.

\section{LITERATURE REVIEW}

\section{Overview of INCOTERMS ${ }^{\circledR} 2020$}

The International Commercial Terms (Incoterms $\left.{ }^{\circledR}\right)$ are a set of internationally accepted definitions and rules of interpretation for most common commercial terms used in contracts for the sale of goods (ICC, 2019). Incoterms ${ }^{\circledR}$ specify in detail the rights, duties, obligations and responsibilities of sellers and buyers in the fulfillment of their contractual obligations, in relation to the delivery of goods and the delivery-related services such as e.g. customs clearance and transport movements (Bergami, 2013).

Incoterms ${ }^{\circledR}$ are issued by the International Chamber of Commerce (ICC), which proposed the first set of uniform interpretation rules of trade terms in 1936 to address the problem of different interpretations of trade terms in different countries and branches of industry and thus provide greater certainty regarding the actual content of the contract of sale. Nowadays, the Incoterms ${ }^{\circledR}$ are used worldwide and have become the international standard for the interpretation of the most frequently terms in foreign trade (Davis \& Vogt, 2021; ICC, 2021; Malfliet, 2011).

Approved worldwide by governments, legal authorities, and business professionals, the use of Incoterms $^{\circledR}$ is however not obligatory. As the ICC is not a governmental organization, it cannot make laws, however, it can recommend solutions and make rules that traders may follow on a voluntary basis, through incorporation of the these rules into contracts of sale (Bergami, 2013). Thus, Incoterms ${ }^{\circledR}$ are a tool offered to companies which can choose to apply them or not. Still, the decision not to use Incoterms ${ }^{\circledR}$ in a contract can cause significant difficulties when determining the customs value of goods, making them quasi-compulsory in some countries (Hien et al., 2009).

Incoterms ${ }^{\circledR}$ clearly define the tasks, costs and risks involved in the delivery of goods as a part of purchase and sales transactions (ITA, 2021). Incoterms ${ }^{\circledR}$ address three important questions: 1) Which delivery tasks will be performed by the importer and exporter (e.g. who organizes carriage or insurance of the 
goods or who obtains shipping documents and export or import licenses)?; 2) How will delivery costs be distributed between the buyer and seller?; and: 3 ) When does the risk pass from seller to the buyer under each of these rules? (Debattista, 2020; Yaakub et al., 2018). Incoterms ${ }^{\circledR}$, therefore, precisely define several elements: the seller's and buyer's delivery obligations, the risk transfer between contract parties, the distribution of costs between the seller and the buyer, and the responsibility for obtaining the transportation documents (Chevalier, 2000). In a codified form (three-letter trade terms) they convey a lot of information regarding how the contract parties are going to allocate certain risks and responsibilities between them, reflecting business practice in contracts for the sale and purchase of goods.

Since the trade terms must harmonize with the emerging new business patterns and need to be adapted to the changing commercial and logistical practices, the ICC issued revised versions of Incoterms ${ }^{\circledR}$. The modernized sets of rules were published in the years: $1953,1967,1976,1980,1990,2000$, 2010 and 2020. The Incoterms ${ }^{\circledast} 2010$ introduced two new rules (DAT and DAP), and eliminated four previously used terms (DEQ, DES, DDU and DAF). Incoterms ${ }^{\circledR} 2020$ replaced DAT by DPU (Delivered at Place Unloaded). The latter change was made to eliminate the word "terminal" and thus avoid the confusion of assuming (wrongly) that when the DAT clause is used, the place of destination of delivered goods must be a terminal understood as a "terminal building" (Piltz, 2020).

Incoterms ${ }^{\circledR} 2020$ are a set of 11 rules, divided into two groups: universal trade terms, that apply to multiple modes of transport (including land, air and waterway transportation), and single-modal trade terms, that are exclusively designed for sea and inland waterway transportation (Wood \& Aversa, 2019; Piltz, 2020). Through this classification, already introduced in an earlier version of Incoterms ${ }^{\circledR}$, the ICC wished to prevent the "maritime" terms specifically designed for transport by waterway - from being used when the universal, multimodal terms would be more suitable (Malfliet, 2011; Piltz, 2020). The waterway Incoterms ${ }^{\circledR}$ rules presuppose that both the place of delivery and the place of destination are at a port and should not be used if the selling party delivers containerized goods (Piltz, 2020).

Multi-modal, universal Incoterms ${ }^{\circledast}$ that can be applied in contracts involving delivery by various means of transport include seven terms: EXW (Ex Works); FCA (Free Carrier); CPT (Carriage Paid To); CIP (Carriage and Insurance Paid to); DAP (Delivered At Place); DPU (Delivered Place Unloaded); DDP (Delivered Duty Paid). Single-modal Incoterms ${ }^{\circledR}$ that are intended for sea and inland waterway transportation only, comprise four terms: FAS (Free Alongside Ship); FOB (Free On Board); CFR (Cost and Freight); CIF (Cost, Insurance and Freight).

In previous versions of Incoterms ${ }^{\circledR}(1990,2000)$, the terms were presented according to the balance of obligations between the parties of the contract and divided into four groups $(E, F, C, D)$ (Shiphub, 2020). The duties of the seller related to the delivery increase progressively from the E, F, C to the $D$ group, while the responsibility of the buyer diminishes accordingly. Many authors still prefer this "traditional" classification as it is still suitable from an educational point of view, taking into account methodological-dogmatic identification criteria (Malfliet, 2011; Piltz, 2020).

In this approach four groups of trade terms can be distinguished:

- E group: contains only one rule (EXW - Ex Works) obliging the seller to place the goods at the disposal of the buyer at the seller's premises, on the agreed date or within the agreed period of time. EXW requires that the seller makes the goods available for collection by the buyer at a certain place (and notifies the buyer of the collection date/period), packed and marked, but not loaded. The transport of the goods as well as customs clearance formalities are the responsibility of the buyer.

- F group: the F- terms (FCA - Free Carrier, FAS - Free Alongside Ship, FOB - Free On Board) impose on the buyer the obligation for bearing the cost and risk of the main international carriage. However, the seller is obliged to deliver the goods to the carrier chosen by the buyer at a certain place of delivery and to clear them for export at his own expense. Depending on the delivery location in the F-term used, the seller may also be obliged to load the goods on the means of transport. The buyer must organize and pay for the further transport (bearing the risk of the main carriage) and import clearance into the country of destination.

- C group: contains four terms (CFR - Cost and Freight; CIF - Cost Insurance and Freight, CPT - Carriage Paid To and CIP - Carriage and Insurance Paid To), according to which the seller pays for the main international carriage, but does not bear the risks thereof. Risks pass to the buyer as soon as the goods 
are handed over to the carrier at the place of delivery. In contrast to the other groups of Incoterms ${ }^{\circledR}$, in the case of applying the C-terms the place of delivery and transfer of risks is not the same as the place of taking over the goods and transfer of costs from the seller to the buyer (so-called two-point clauses).

- D group: as a typical characteristic of all terms of the D group (DAP - Delivered at Place, DPU Delivered at Place Unloaded and DDP - Delivered Duty Paid), the seller bears all costs and risks related to the delivery of goods up to the indicated delivery point in the country of destination, where the buyer is obliged to take over the goods. However, the buyer remains responsible for clearing the goods for import except for the DDP clause according to which the seller must complete all the formalities related to the clearance of imported products.

According to ICC/Paris findings, the Incoterms ${ }^{\oplus}$ clauses are used in $90 \%$ of all international sales contracts and became a widespread international standard (Piltz, 2020). They influence various business aspects from sourcing to sales, from legal to finance, from business operations to corporate strategy. However, despite the fact that many enterprises already interact closely with Incoterms ${ }^{\circledR}$ rules in their day-to-day business, their power is often underestimated (Deloitte, 2020). Therefore, it is very important to broaden the knowledge on the content and proper use of Incoterms ${ }^{\circledR}$. Incoterms ${ }^{\circledR}$ should not be taken as an obligation but as an opportunity to improve the efficiency of an international deal (Hien et al., 2009; Huuhka, 2019).

\section{Selection of the appropriate trade term}

With the progressing globalization and internationalization of the world economy in recent decades, the number of negotiated contracts has increased significantly, and at the same time they have become more complex and diverse. Therefore, specifying delivery terms in accordance with Incoterms ${ }^{\circledR}$ is crucial since they add clarity and understanding between the parties to the agreement, representing often different cultures, religions, languages and so on. Parties must have an understanding of how different Incoterms ${ }^{\circledR}$ are used, as well as how to choose the appropriate term. Misused Incoterms ${ }^{\circledR}$ can have negative effect on payment, delivery schedules and generate extra costs; they may result in weak inventory control or a bad customer experience (Huuhka, 2019).

Risk, cost, country of destination, time, product and payment conditions influence the Incoterms ${ }^{\circledast}$ rule choice, which respectively, have a huge impact on international trade. Incoterms ${ }^{\circledR}$ must be selected by taking into careful consideration various affecting variables. Properly used Incoterms ${ }^{\circledR}$ are cost effective and lead to the improvement of the company's financial indicators (Gardner, 2012; Huuhka, 2019).

Several factors have to be considered in order to ensure a company uses the right Incoterms ${ }^{\circledR}$ rules to maximize efficiency. According to Malfliet (2011) they include:

- the nature of the goods: transported in containers, manufactured goods, bulk goods, etc.;

- the means of transport: maritime, non-maritime, multimodal;

- the terms of payment and the documentary requirements corresponding to these terms;

- the ability and the efficiency of the seller or the buyer to carry out the obligations related to the delivery of the contracted goods.

The author argues that EXW is not in line with international trade practice. Contract parties are recommended to choose FCA seller's premises instead. Also, in his opinion, the fact that FCA, CPT and CIP rules designate the point of delivery at the moment they are handed over to the carrier, and impose less demanding documentary obligations makes them suitable for multimodal and container transportation. Traders are recommended to use these terms instead of the maritime terms. The author also believes that SME exporters tending to choose EXW or F-terms may miss an important opportunity associated with organizing transport themselves and charging a commission to the buyer for the service rendered. The advantages of the seller organizing transport include among others: the possibility of consolidating shipments and thus reducing storage and transport costs and aligning the date of shipment with the production planning; choosing a reliable carrier, control over the quality of goods until they have reached the country of destination and collecting the documents necessary for payment under the letter of credit and other specific documents (Malfliet, 2011). 
Hien et al. (2009) aimed to identify the main environmental factors taken into consideration when deciding which Incoterms ${ }^{\circledR}$ rules to use and to analyze the influence of the choice of trade terms on company export performance. Based on study by Duncan (1972) and their own review of the literature, the authors have prepared a list of the environmental factors, which contains 10 factors: international experience, shipment value, habits and practices of the organization, financial resources of the organization, chosen mode of transportation, client's characteristics, country risk, competitive intensity and regulations of the destination country. The findings highlight the significance of taking into consideration both the internal and external business environments in the selection process for Incoterms ${ }^{\circledR}$ and its contribution to improved export performance. The achieved results have proved that considering relevant environmental factors when selecting $\operatorname{lncoterms}{ }^{\circledR}$ is a variable that is positively correlated to export performance, as it may reflect management's ability to understand the legal environment of the company. The authors believe that constituting one of the key issue in negotiating international sales contracts, the choice of Incoterms ${ }^{\circledast}$ appears to be also a fundamental factor contributing strongly to the company export success.

Suraraksa et al. (2020) identified four factors influencing the decision-making of Incoterms ${ }^{\circledR}$ of manufacturers in the automotive parts sector in Thailand. They include: operating costs, cooperation and bargaining power, knowledge and understanding and operation duration. They constitute the main choice criteria of Incoterms ${ }^{\circledR}$ which were then divided into fifteen sub-criteria. The findings indicated that "operating costs" were the first and most important criterion which the manufacturer considers when deciding which of the Incoterms ${ }^{\circledR}$ to choose. The result was consistent with the priority of the secondary criteria as three operating costs sub-criteria, which included "annual budget", "transportation expenses" and "value of products", were ranked the highest. "Knowledge and understanding", referring to the state of knowledge on international trade and Incoterms ${ }^{\circledR}$, was ranked second. Four sub-criteria which have been assigned to this criterion include: "Incoterms ${ }^{\circledR}$ rules", "experience in choosing Incoterms ${ }^{\circledR}$ ", "international trade laws" and "complicated documents". Relatively less significant was "cooperation and bargaining power", involving such sub-criteria as: "negotiation between the buyer and seller", "trust between the seller and buyer", "collaboration within the company", "agreed terms between the seller and buyer". "Operation duration" divided into four sub-criteria: "payment terms", "transportation period", "duration to change carriers", "duration for risk taking", ranked lowest among the criteria for consideration.

Among factors affecting the choice of Incoterms ${ }^{\circledR}$ Stojanović and Ivetić (2020) pay attention not only to distance between countries, but also to GDP per capita and national policy decisions. The Incoterms ${ }^{\circledR}$ rule is aimed at supporting transport and insurance sector in a domestic economy.

Unal and Metin (2021) examined the factors that influence Incoterms ${ }^{\circledast}$ selections with the purpose to identify potential differences in the way they affect exporters and importers. For this purpose, they analyzed the importance weights of each factor, using Fuzzy Analytical Hierarchy Process (FAHP), and ranked them for both two parties. The authors grouped the 13 sub-criteria under three main criteria validated by foreign trade experts which were used to conceptualize a model of the study. The main criteria and their assigned sub-criteria were as follows: 1) Resource-advantage criterion - including sub-criteria such as firm size, staff characteristics, relations with customers/suppliers, relations with forwarding agents; (2) Efficiency-cost criterion - involving sub-criteria such as mode of transportation, mode of payment, type of goods, cost of goods, cost of transportation; (3) Legitimacy environment criterion - covering the secondary criteria such as complexity of transportation, risks, customs/bureaucracy and distance.

Findings of the study revealed that the key factor influencing the selection of international commercial terms for both exporters and importers was "transportation costs" while the least important one was "firm size". Four factors which included: "relations with forwarding agents", "type of goods", "complexity of transportation" and "distance" influenced importers and exporters differently in their selection processes. Relations with forwarding agents and distance were found to be more influential for exporters while the type of goods and complexity of transportation had a bigger impact on importers. In general, cost related factors influenced the decisions on Incoterms ${ }^{\circledR}$ the most and except of a few factors, no significant divergence between the selection decisions of importers and exporters was found. 
Delloite (2020) in their report proposed an overall Incoterms ${ }^{\circledR}$ check-up an organization should perform to ensure that they use the right Incoterms ${ }^{\circledR}$ rules to maximize efficiency.

According to the authors, certain factors may have a positive impact on a company's value chain and should be considered in the decision-making process on Incoterms ${ }^{\circledast}$. Among others, Incoterms ${ }^{\circledR}$ rules should be in line with their intention (for instance maritime terms should not be used for containerized, multimodal transportation); Incoterms ${ }^{\circledR}$ rules should be in accordance with a contract party's intended role in the export and the obligations arising from it. Additionally, using software a company must assure that software solutions are adjusted to properly reflect Incoterms ${ }^{\circledR}$ rules and support the requirements of their handling; the choice of Incoterms ${ }^{\circledR}$ should be in compliance with the purposes of accounting and invoicing; a company should implement or review the sales and procurement calculation schemes based on Incoterms ${ }^{\circledR}$.

Our research is an attempt to further investigate this problem and fill the gap in knowledge regarding the right use of Incoterms ${ }^{\circledR}$, focusing on decision making on trade terms in companies operating on the Polish market and involved in foreign trade.

\section{RESEARCH METHODOLOGY}

The main objective of this study was to find out which factors affect the selection of particular terms in the international business contracts and to assess their relative significance. We implemented a mixed methods research to reach this goal. Specifically, the quantitative and qualitative data in this study were collected through a survey carried out among export/import managers of companies operating in Poland. The research process was divided into five phases commencing with the identification of the research objective (Figure 1).

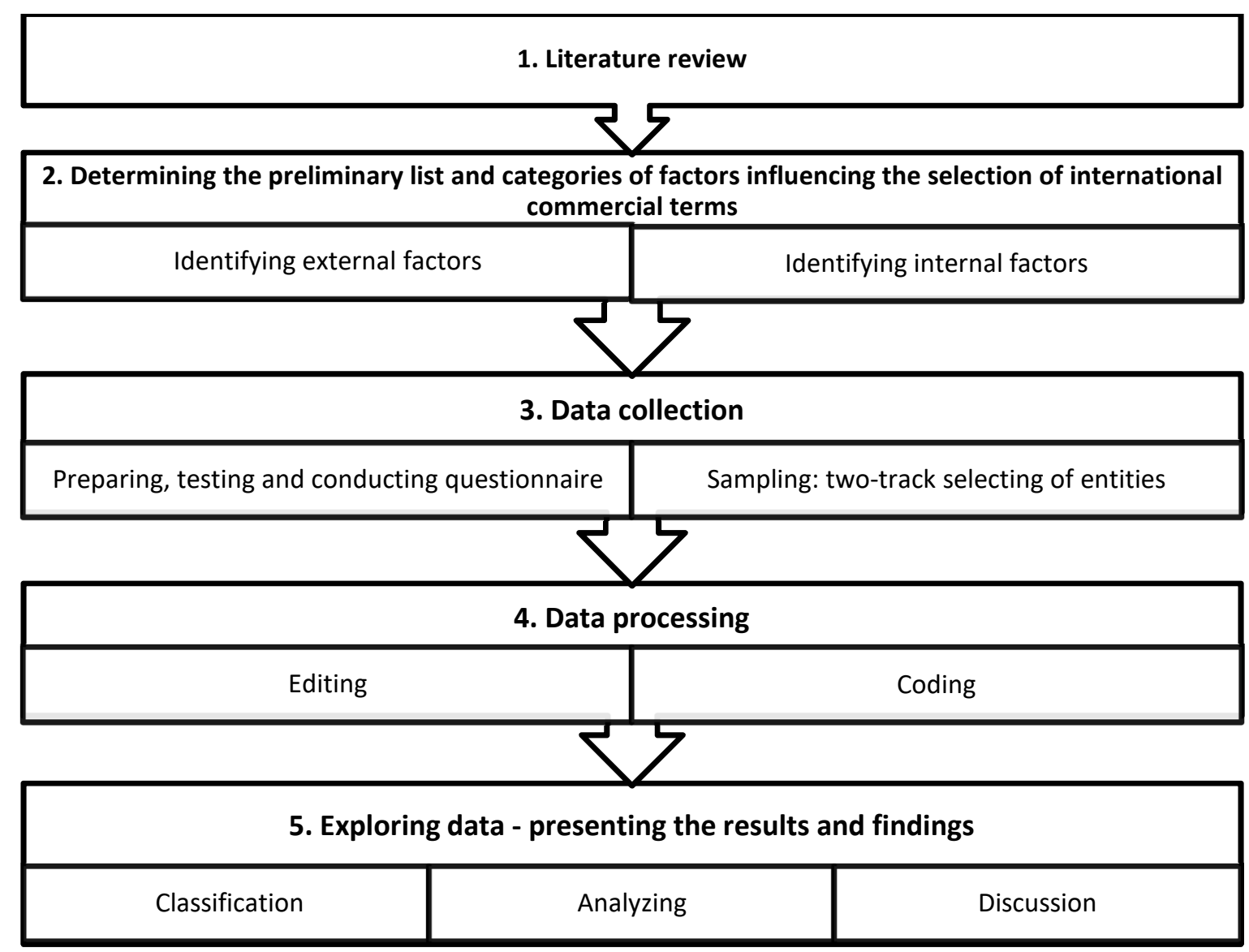

Figure 1. Research conceptualization Source: own elaboration. 
First, we reviewed the relevant literature focusing on using Incoterms ${ }^{\circledR}$ in international trade operations and addressing the issues with regard to the selection of the appropriate rule. Secondly, considering the preliminary list of factors, selected on the basis of the literature review, we decided to examine two groups of factors potentially influencing the Incoterms ${ }^{\circledR}$ selection. The first group of factors includes "external factors". It is made up of the factors of external business environment and independent of the organization that can affect the choice of commercial terms. While the second group of determinants - "internal factors" - refers to factors from internal business environment, i.e. factors within the company and under control of it, which can also impact the company selection of Incoterms $s^{\circledast}$. In the third step we created an online questionnaire for the respondents to verify the factors that they take into account in making decisions regarding Incoterms ${ }^{\circledast}$ and to find out their priorities when considering delivery terms. We used the Google Forms platform to create an online questionnaire automatically hosted via a unique URL. The questionnaire was divided into five thematic sections. The characteristics of the firms was provided in some detail through the first set of questions. The European definition of enterprise was applied to determine the category of the entities. We used Statistical classification of economic activities in the European Community (NACE rev.2) to identify the categories for production of goods and services of the surveyed companies. Then, in the second part, the respondents were asked to indicate their preferences and practices related to the application of Incoterms ${ }^{\circledR}$ in company operations. The third part of questionnaire contains questions referring specifically to factors influencing their decision-making on Incoterms ${ }^{\circledast}$. The next section explores methods and forms of enhancing knowledge and skills essential for the proper use of Incoterms ${ }^{\circledR}$. The questions providing characteristics of survey respondents are included in the last part of our questionnaire. The questionnaire went through pilot testing on a small sample of 37 graduates from the Cracow University of Economics and was subsequently modified and then used to collect data.

We selected two methods of targeting appropriate participants who might be interested in taking part in our research on Incoterms ${ }^{\circledR}$. The potential respondents were selected in 2 different ways. Firstly, we searched for the entities operating in the Polish market and involved in foreign trade. For this purpose we used Orbis computer database providing access to approximately 400 million entities worldwide. The stratified random sampling was applied according to the following criteria: active companies, operating in the Polish market, internationalized businesses (at least exporting and with or without share of foreign capital). We obtained the sample of 3,129 entities. Then, in order to select the companies operating in the market, we limited our sample size by introducing additional criterion of financial data availability. We considered the operating revenue (turnover) for 2019 at the latest. Finally, we selected 746 companies operating in the Polish market and trading with foreign partners and sent our questionnaire to their export and import managers. In order to increase the sample size we additionally sent an invitation to our students and graduates of International Economic Relations at the Cracow University of Economics asking them to pass the questionnaire to export/import managers in their companies or even take part in our survey (as experts and business practitioners). Postgraduates studying international trade were also asked to participate in the survey. A total of 695 emails were sent to this second group.

We used an e-mail survey and sent 1441 emails to our potential respondents. A total of 121 submissions of completed questionnaires were obtained. The reasons why the rest of our potential respondents were not included in the final sample were as follows:

- 9.6\% (139) - refusal to take part in the survey;

- $24.8 \%$ (358) - wrong e-mail address (regarding mostly postgraduates $-70 \%$ of this category);

- 53.6\% (823) - not responding to our e-mails.

A total of 121 complete questionnaires were gathered. The survey was conducted in September 2021.

The identified research sample is dominated by large and medium companies according to the European classification, which account for nearly $87 \%$ of the total study population. More than half of the companies were classified as dealing with manufacturing. In the survey sample there was also a relatively large representation of companies operating in wholesale and retail trade sector as well as 
mining and quarrying and construction sector. Approximately $73 \%$ of the firms in the sample are internationally active (in exporting and importing), being at the same time involved in sales and purchases on the domestic market. Nearly half of the surveyed companies import only one type of product representing a specific degree of processing (raw materials, intermediate or final products). The remaining companies purchase at least two types of products abroad, with nearly one in four companies importing goods classified as each stage of manufacturing (Table 1 ).

Table 1. Characteristics of the research sample

\begin{tabular}{|c|c|c|c|}
\hline \multicolumn{2}{|l|}{ Size of the company (in \%) } & \multicolumn{2}{|l|}{ Types of economic activities according to NACE rev.2 (in \%) } \\
\hline $\begin{array}{l}\text { large } \\
\text { medium-sized } \\
\text { small } \\
\text { micro }\end{array}$ & \begin{tabular}{r|}
72.8 \\
14.0 \\
6.6 \\
6.6 \\
\end{tabular} & $\begin{array}{l}\text { Agriculture, forestry and fishing } \\
\text { Mining and quarrying } \\
\text { Manufacturing } \\
\text { Construction } \\
\text { Wholesale and retail trade, repair of motor vehicles } \\
\text { and motorcycles } \\
\text { Accommodation and food service activities } \\
\text { Financial and insurance activities } \\
\text { Other activities }\end{array}$ & \begin{tabular}{r|}
0.8 \\
14.9 \\
52.1 \\
9.9 \\
\\
17.4 \\
0.0 \\
5.0 \\
0.0 \\
\end{tabular} \\
\hline \multicolumn{2}{|l|}{ Types of company turnover (in \%) } & \multicolumn{2}{|l|}{ Export share in total sales revenues (in \%) } \\
\hline $\begin{array}{l}\text { exports, imports, domestic sales and purchases } \\
\text { exports, domestic sales and purchases } \\
\text { exports and imports } \\
\text { imports } \\
\text { imports, domestic sales and purchases } \\
\text { domestic sales and purchases } \\
\end{array}$ & \begin{tabular}{r|}
72.7 \\
5.0 \\
2.5 \\
6.6 \\
3.3 \\
9.9 \\
\end{tabular} & $\begin{array}{l}\text { less than } 10 \% \\
\text { from } 10 \% \text { to } 30 \% \\
\text { from } 30 \% \text { to } 50 \% \\
\text { more than } 50 \% \\
\text { we do not export }\end{array}$ & $\begin{array}{r}8.3 \\
15.7 \\
25.6 \\
37.2 \\
13.2\end{array}$ \\
\hline \multicolumn{2}{|l|}{ Types of imported products (in \%) } & & \\
\hline $\begin{array}{l}\text { raw materials } \\
\text { raw material, intermediate products } \\
\text { raw materials, intermediate products and final } \\
\text { products } \\
\text { raw materials and final products } \\
\text { intermediate products } \\
\text { intermediate products and final products } \\
\text { final products } \\
\text { we do not import }\end{array}$ & $\begin{array}{r}21.5 \\
5.0 \\
\\
23.1 \\
1.7 \\
7.4 \\
21.5 \\
19.8 \\
0.0\end{array}$ & & \\
\hline
\end{tabular}

The research sample was also presented taking into account the respondents' position in the hierarchy of their organizations and the length of their working experience.

Table 2. Basic information about the respondents

\begin{tabular}{|l|r|l|r|}
\hline \multicolumn{2}{|c|}{ Position (in \%) } & \multicolumn{2}{c|}{ Work experience (in \%) } \\
\hline Assistant & 14.9 & Up to one year & 9.9 \\
Specialist & 35.5 & More than one and not more than five years & 41.3 \\
Junior manager & 28.1 & Between five and ten years & 9.1 \\
Senior manager & 16.5 & Over 10 years & 39.7 \\
President/Director & 1.7 & & \\
Other & 3.3 & & \\
\hline
\end{tabular}

Source: own study.

Respondents are mostly specialists and junior managers, so they are on middle and lower-middle - level positions in the hierarchy of their organizations. $16.5 \%$ are senior managers and $2.7 \%$ are top executives. It is interesting to note that about half of respondents have experience of less than 5 years, 
out of them $41.3 \%$ possess experience of more than one and not more than five years, at the same time $39.7 \%$ have much longer work experience - over 10 years (Table 2 ).

The collected raw data were appropriately prepared, organized and converted into usable information in the next phase of our research. Then we took all collected qualitative data and assigned them to a set of meaningful and cohesive categories. Responses in the questionnaire were numbered. We selected numerical coding. We adopted a designation of 1 or more for the answer related to the research objective. The higher was the assigned value, the more the response was positively linked with the aim of the study.

In the last phase, we analyzed the collected quantitative data and coded qualitative data. In our research we tried to use elements of descriptive statistics. Through this analysis we attempted to explore the importance of external and internal factors affecting the use of Incoterms ${ }^{\circledR}$ in companies' business operations.

\section{RESULTS AND DISCUSSION}

On the basis of the obtained results, it can be concluded that the most frequently used Incoterms ${ }^{\circledR}$ rule in export transactions was EXW, followed by DAP, CIF and FCA. These results show the variation between companies in this respect, which may reflect the fact that these companies operate in different industries with their specific needs as regards the delivery terms and their own commercial habits. However, EXW's dominance is quite surprising and not in line with other studies (Suraraksa et al., 2020; Schaefer, 2017) that indicate FCA as the most popular Incoterms ${ }^{\circledR}$ rule. This can be explained in part by the fact that the sample has a large representation of big companies that have strong bargaining power towards small recipients and they tend to choose the terms which do not require taking on additional responsibilities and/or risks. But it may also mean overestimating EXW by exporters, and confirm the point of view presented by Malfliet (2011), that not all exporters understand the nuances of Incoterms ${ }^{\circledR}$. In import transactions, most frequently chosen Incoterms ${ }^{\circledR}$ are: DAP, FOB and CIF. As in exports, this may result from the large share of large companies with high bargaining power and industry specificity. But the high proportion of marine terms may also indicate their excessive use (where perhaps it would be better to use universal formulas) and a lack of awareness of their weak points (Table 3).

Table 3. Incoterms ${ }^{\circledR}$ most frequently used in international transactions (in \%)

\begin{tabular}{|l|r|l|r|}
\hline \multicolumn{2}{|c|}{ In exports } & \multicolumn{2}{c|}{ In imports } \\
\hline EXW & 23.1 & EXW & 1.7 \\
FCA & 10.7 & FCA & 5.0 \\
FOB & 1.7 & FOB & 16.5 \\
CIF & 13.2 & CIF & 13.2 \\
CPT & 0.8 & DAP & 36.4 \\
DAP & 16.5 & DDP & 8.3 \\
DPU & 0.8 & No import transactions/no using Incoterms & \\
DDP & 3.3 & & 19.0 \\
No export transactions/no using Incoterms & & \\
\hline
\end{tabular}

Source: own study.

According to the survey results, $80 \%$ of the companies were involved in export and import transactions and use Incoterms ${ }^{\circledR}$ to define delivery terms. About $10 \%$ of the surveyed companies did not export.

The factors affecting the choice of Incoterms ${ }^{\circledR}$ indicated by the respondents were presented in the subsequent three figures.

The findings indicated that legal regulations on foreign markets and geographical distance were the external factors which had the strongest influence on companies' decision-making on Incoterms ${ }^{\circledR}$. It was also observed that prices for international transport and freight forwarding services and existing transport and logistics infrastructure (domestically and abroad) as well as risks on foreign markets (including political risks) had the big significance for choosing the Incoterms ${ }^{\circledast}$. On the other hand, most of companies don't consider domestic and foreign competition as a factor strongly affecting their decisions 
on Incoterms ${ }^{\circledR}$ which may suggest that the use of Incoterms ${ }^{\circledR}$ as a tool for building competitive advantage is often underestimated (Figure 2).

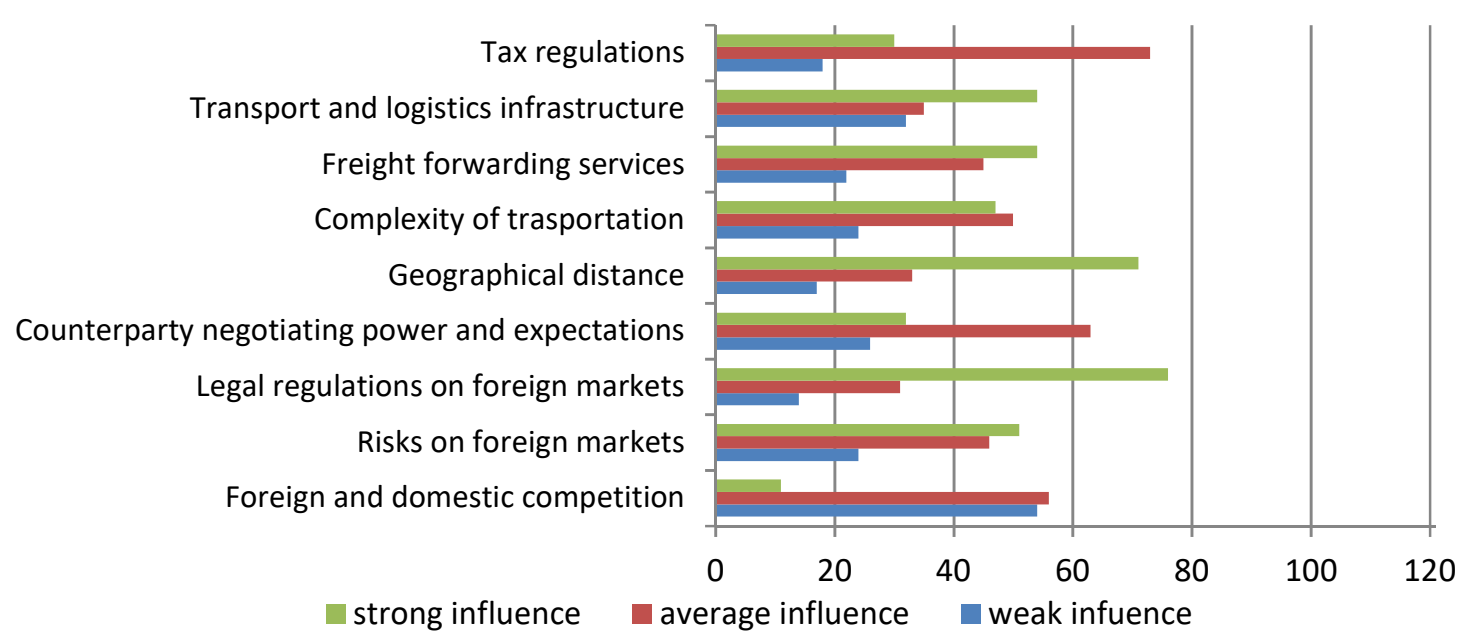

Figure 2. Respondents' view on external factors affecting the selection of Incoterms ${ }^{\circledast}$ (number of indications) Source: own elaboration.

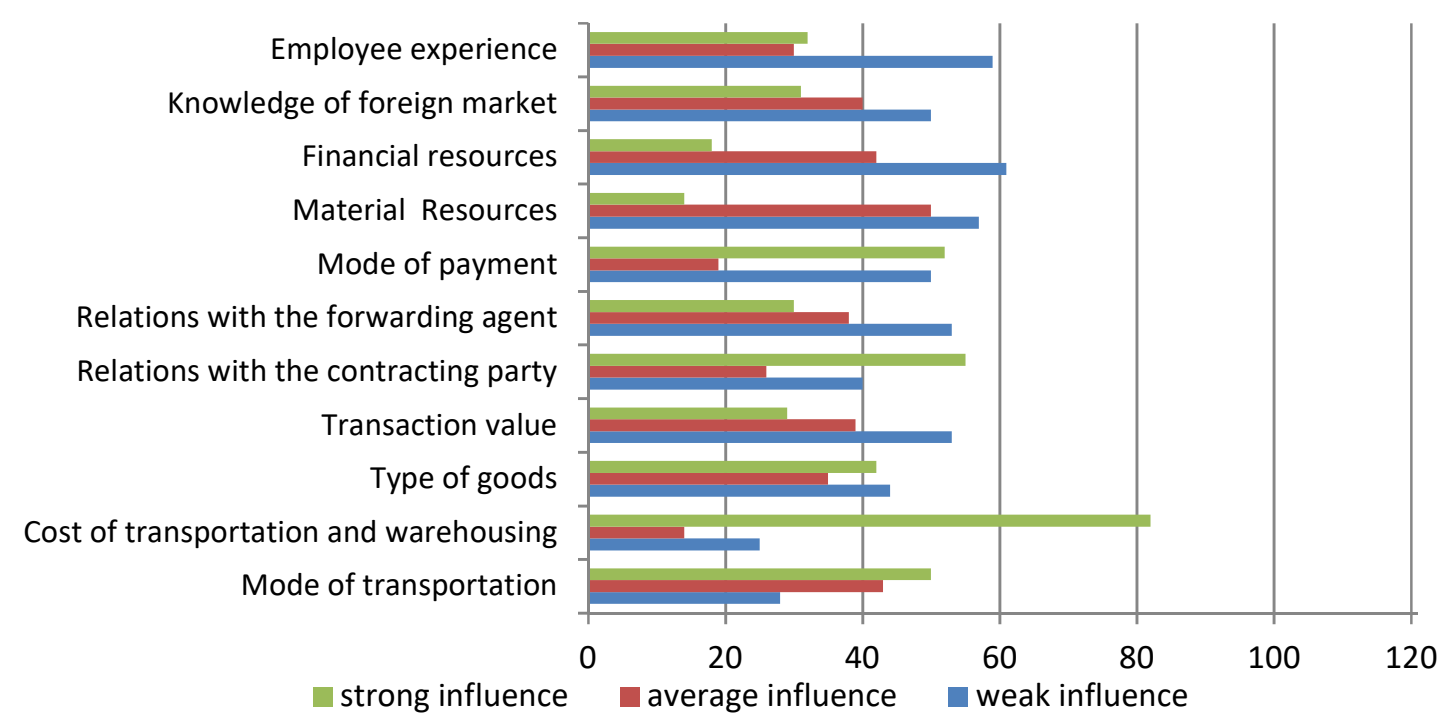

Figure 3. Respondents' view on internal factors affecting the selection of Incoterms ${ }^{\circledR}$ (number of indications) Source: own elaboration.

Among the internal determinants, the cost of transportation and warehousing was the factor having the strongest influence on the selection of Incoterms ${ }^{\circledast}$. Furthermore, another factors considered to have a great influence on decisions on Incoterms ${ }^{\circledR}$ (however, relatively substantially weaker than the factor mentioned in the first place) are relations with the contracting party, mode of payment and mode of transportation. Among the factors assessed as having a relatively small impact on the choice of Incoterms ${ }^{\circledast}$ are, among others, employees experience, financial and material resources and transaction value (Figure 3 ). The results of the research are partly in line with other similar studies. One surprise, however, is the relatively low power of influence attributed to the value of a single transaction and the financial resources of a company. Also many respondents seem not to see a link between the choice of Incoterms ${ }^{\circledR}$ and the method of payment. 


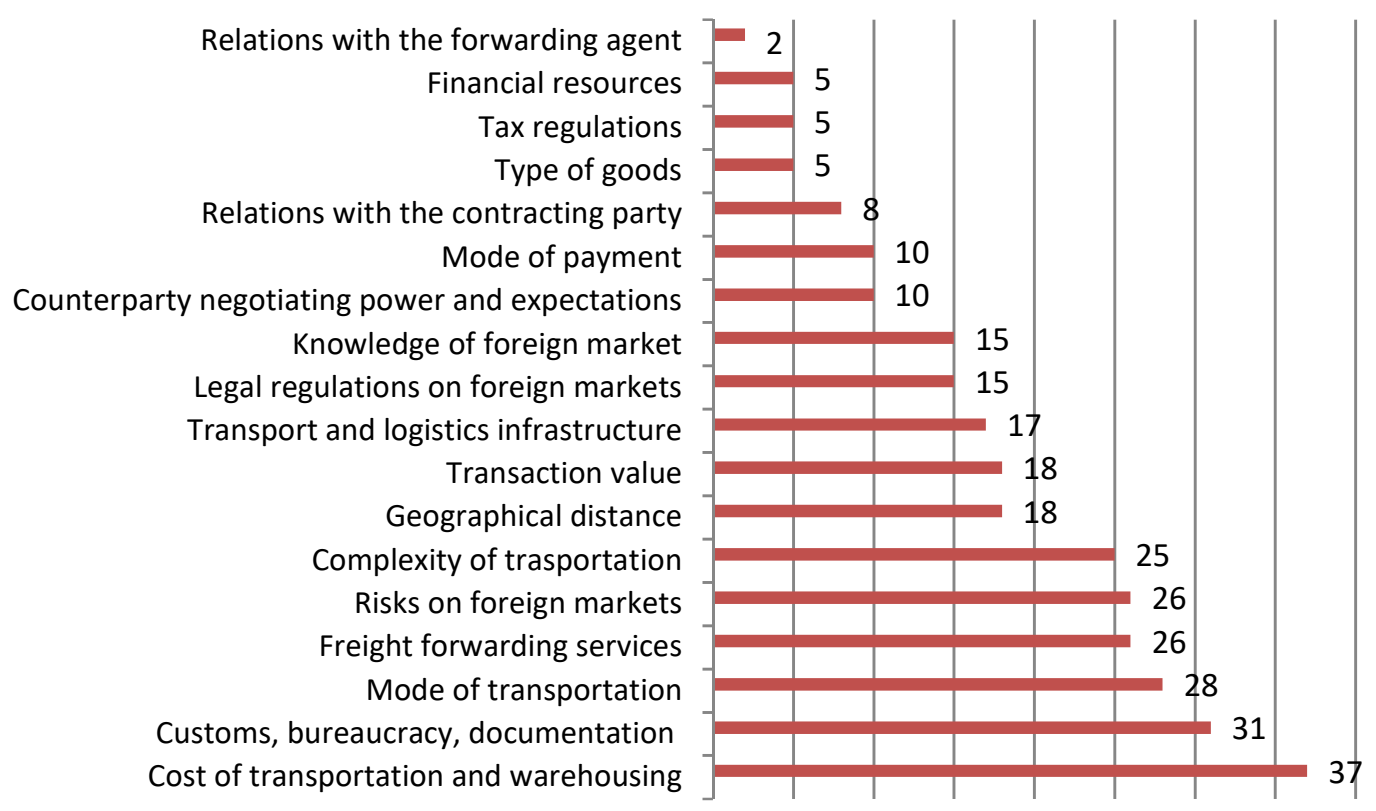

Figure 4. Respondents' view on both external and internal factors (in \%) Note: The frequency of indications calculated in \%. It does not sum up to $100 \%$ Source: own elaboration.

Analyzing the influence of both external and internal factors on companies' decisions regarding Incoterms ${ }^{\circledR}$, it was found that cost of transportation and warehousing is the main factor which companies take into the consideration when selecting Incoterms ${ }^{\circledast}$ customs rules (37\%), followed by bureaucracy, documentation (31\%), mode of transportation (28\%), risks on foreign markets (26\%) and the availability of freight forwarding services (26\%). The factors which are taken into account in choosing Incoterms ${ }^{\circledR}$ to a smallest degree are: type of goods, tax regulations, financial resources, relations with the forwarding agent (Figure 4). The respondents also indicated additional factors (not included in the list), such as, for example, efforts to synchronize the date of shipment with production plans, and the use of the possibility of consolidating deliveries.

Facilitating the implementation of operational activities by choosing an appropriate rule

Facilitating of the implementation of company's strategy through the choice of an appropriate rule

Decreasing of delivery costs and increasing of company profits by selecting the right rule

Avoidance of disputes between coontractual parties arising from differences in the interpretation of Incoterms

Enhanced transparency and clear definition of rights and obligations of the contractual parties in delivery terms

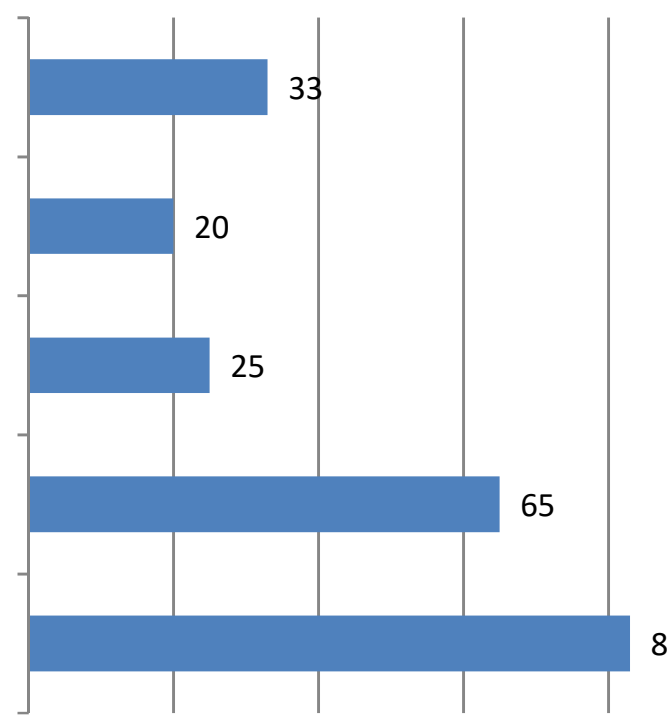

- Number of indications

Figure 5. Respondents view on advantages of using the Incoterms ${ }^{\circledR}$ Source: own elaboration. 
Among the benefits of using Incoterms ${ }^{\circledast}$, the respondents mentioned mainly enhanced transparency and clear definition of contractual rights and obligations regarding the delivery and the avoidance of disputes arising from differences in the interpretation of delivery terms. The other listed benefits received a lower number of respondents' indications (Figure 5). This may indicate that managers perceive Incoterms ${ }^{\circledR}$ mainly as a way of clarifying the rights and obligations of the contractual parties, which allows avoiding or facilitating the resolution of potential conflicts. Still, to a lesser extent, they consider them a tool for building a strategic competitive advantage and obtaining additional financial gains This latter finding is in line with the outcome of the study by Deloitte (2020).

Incoterms ${ }^{\circledR}$ rules influence all business aspects determining various processes within a company, from sourcing to sales, from legal to finance, from business operations to corporate strategy. We asked the respondents if they saw the impact of Incoterms ${ }^{\circledR}$ on selected aspects of the company's operations. The obtained responses are presented in the Table 4 and Figure 6.

Table 4. Respondents' view on the impact of Incoterms ${ }^{\circledR}$ on selected aspects of their business (beyond defining the terms of delivery) in \%

\begin{tabular}{|c|c|c|c|}
\hline Description/Answers & $\begin{array}{c}\text { ob- } \\
\text { served }\end{array}$ & $\begin{array}{l}\text { not ob- } \\
\text { served }\end{array}$ & $\begin{array}{l}\text { don't } \\
\text { know }\end{array}$ \\
\hline The impact of Incoterms ${ }^{\circledR}$ selection on the company's financial performance in export & 24.2 & 8.4 & 67.4 \\
\hline Calculating the selling prices based on Incoterms ${ }^{\circledR}$ & 81.3 & 8.3 & 10.4 \\
\hline Problems with the fulfillment of obligations arising from the Incoterms ${ }^{\circledR}$ chosen & 13.4 & 72.2 & 14.4 \\
\hline Company engagement in a dispute over rights and obligations arising from Incoterms ${ }^{\circledR}$ & 13.5 & 62.5 & 24.0 \\
\hline
\end{tabular}

Source: own study.

On the one hand, Incoterms ${ }^{\circledR}$ are used by one in four surveyed companies when calculating price. On the other hand, however, smaller percentage of respondents believe that the Incoterms ${ }^{\circledR}$ have impact on company's financial performance in exports. The majority of respondents representing the surveyed companies were not involved in disputes arising from the use of Incoterms ${ }^{\circledR}$ in purchase and sales contracts. Only one in ten respondents was informed of the occurrence of disputes relating to the use of Incoterms ${ }^{\circledR}$ in their companies (Table 4). At the same time respondents were aware of the important role that the Incoterms ${ }^{\circledR}$ rules can play in export and import contracts, which was confirmed by the results presented in Figure 6 .

Employees of companies involved in trade have sufficient knowledge on Incoterms ${ }^{\circledR}$ and their strategic importance

Each company should use Incoterms ${ }^{\circledR}$ as part of their commercial contracts.

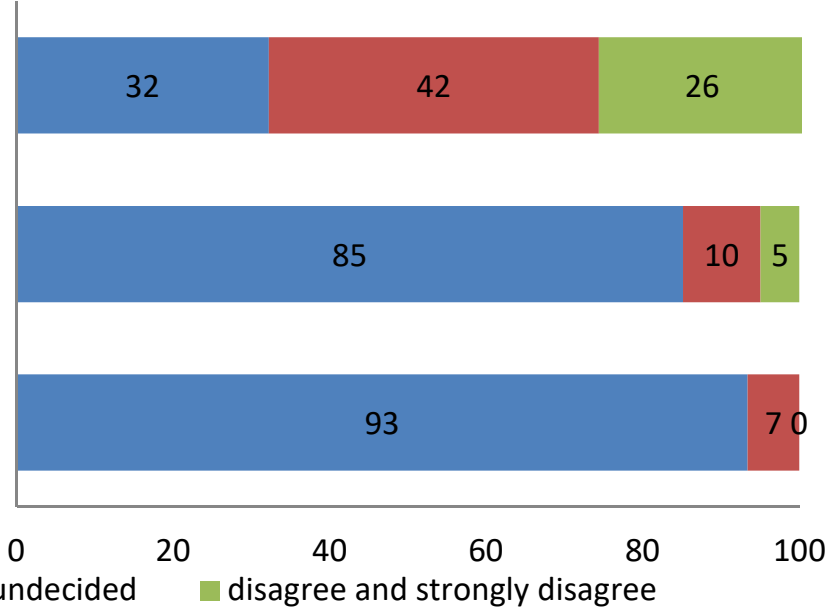

The use of Incoterms ${ }^{\circledR}$ significantly facilitates international trade.

agree and strongly agree

undecided disagree and strongly disagree

Figure 6. Comments provided by the respondents on the importance of Incoterms ${ }^{\circledR}$ in business activities (in \%) Source: own elaboration.

Respondents indicated that the use of Incoterms ${ }^{\circledR}$ can facilitate international trade (93\%), and that they play an important role in concluding sales and purchase contracts (85\%). At the same time, in their view, the employees involved in international trade do not have sufficient knowledge and skills 
to use the Incoterms ${ }^{\circledast}$ rules appropriately (Figure 6). They also recognized the limitations of using Incoterms ${ }^{\circledR}$ in their companies.

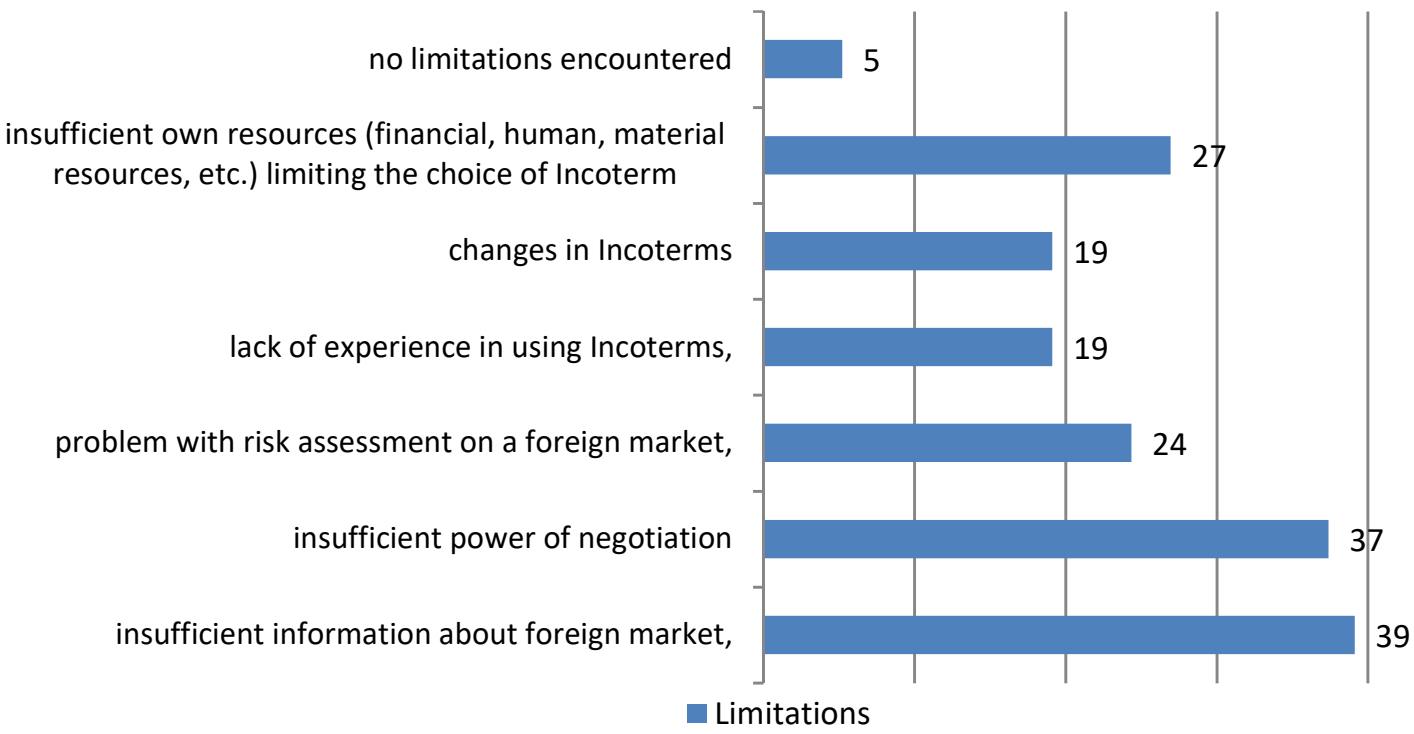

Figure 7. Respondents' view on the limitation in setting of the right delivery terms in purchase/sales contracts (in \%)

Note: The frequency of indications was calculated in \%. It does not sum up to $100 \%$, as respondents could choose more than one answer.

Source: own elaboration.

Among the most frequently highlighted limitations of using Incoterms ${ }^{\circledR}$, respondents mentioned insufficient information about foreign market (39\% of indications) and insufficient power of negotiations (37\%). In nearly one in four companies, insufficient own resources ( $27 \%$ of indications) and foreign market risk assessment ( $24 \%$ of indications) were barriers in choosing the right Incoterms ${ }^{\circledR}$. In addition, one in five respondents indicated a lack of experience in using Incoterms ${ }^{\circledR}$, as well as changes made in subsequent editions of Incoterms ${ }^{\circledR}$ released every 10 years (Figure 7). These latter limitations indicate a need for training in the use of Incoterms ${ }^{\circledR}$. Our survey also supported this respondents' view, as $83 \%$ respondents saw the need to further develop their knowledge and skills in the use of Incoterms ${ }^{\circledR}$. Respondents also selected the most suitable forms of training that in their opinion would be the most effective in acquiring skills needed for the proper application of Incoterms ${ }^{\circledR}$ (Figure 8).

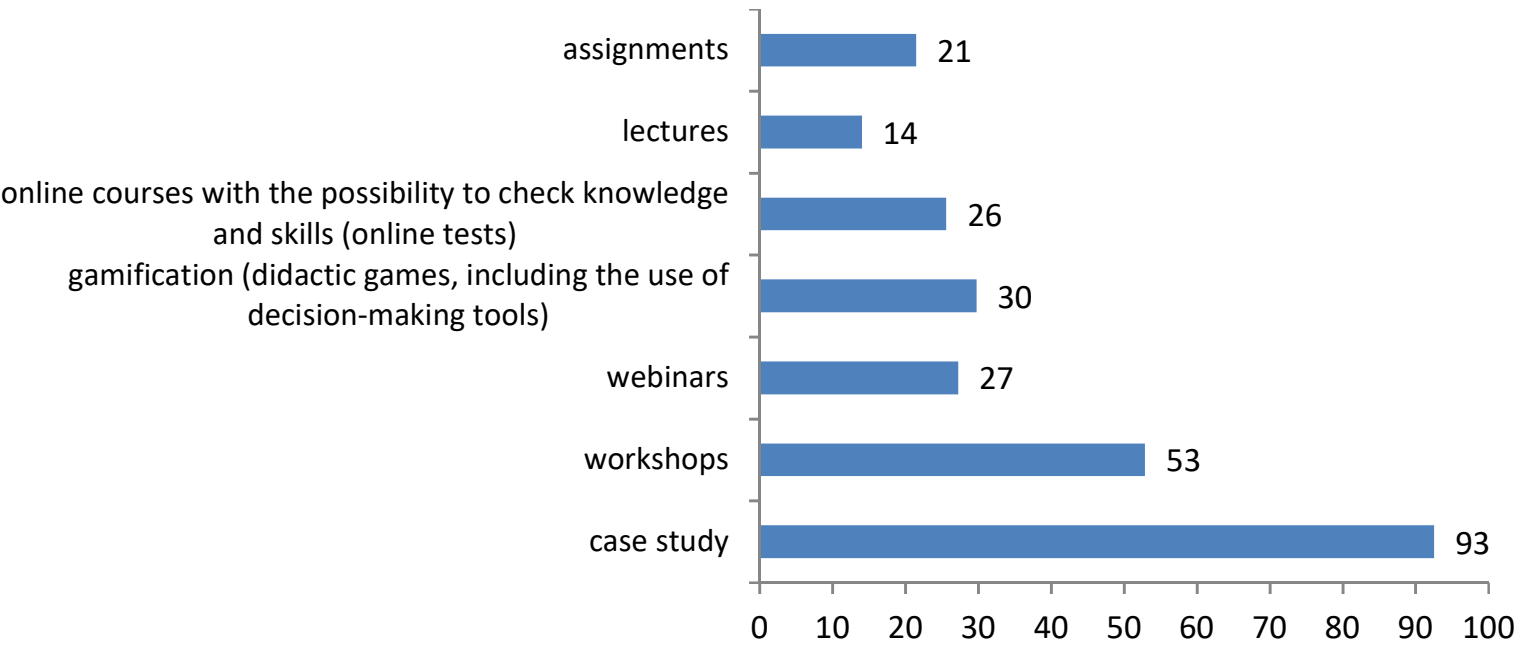

Figure 8. Respondents' view on preferred forms of training concerning implementation of Incoterms ${ }^{\circledR}$ (in \%) Source: own elaboration. 
Case studies and workshops are considered by the majority of respondents (93\% and $53 \%$ of indications, respectively) to be the most popular training in improving the respondents' skills in the use of Incoterms ${ }^{\circledR}$. There would be less interest in gamification ( $30 \%$ of indications), webinars ( $27 \%$ of indications) and online courses ( $26 \%$ of indications) (Figure 8 ).

Our research was limited by company reticence to provide data regarding their engagement in international trade activities. Despite addressing our questionnaire to approximately 1,500 respondents, we manage to obtain about $8 \%$ response rate. Furthermore, our research sample was dominated by large enterprises. This may be due to the fact that small enterprises, which constitute the majority of economic entities in Poland mostly represent a low degree of internationalization or do not conduct foreign trade at all. The applied research method did not enable to verify whether or not a correlation exists between Incoterms ${ }^{\circledast}$ selection and export performance. It only allows to identify the internal and external factors affecting the actual choice of Incoterms ${ }^{\circledR}$ rule and their force of impact on companies' decisions. However, in our opinion the applied methods does not depreciate the cognitive value of the presented article. The obtained results can be a starting points for further study using more advanced methods and covering new areas of analysis such as for example the differences in the use of this tool in companies representing different sectors or different cultures or measuring their impact on business performance.

\section{CONCLUSIONS}

The purpose of this paper was to determine factors which influence the decisions on selection of particular Incoterms ${ }^{\circledast}$ rules in international business contracts in companies operating in Poland. The main problem faced by many companies is making incorrect decisions on Incoterms ${ }^{\circledR}$, without careful consideration of various factors in the Incoterms ${ }^{\circledR}$ selection process, which can affect cost, risks, liabilities and formalities of international transactions. Traders often underestimate their potential, choosing terms without much reflection and continuing to use the same Incoterms ${ }^{\circledast}$ even if other conditions of transactions differ significantly.

On the basis of the obtained results, it can be stated that companies prefer to conclude transactions under Incoterms ${ }^{\circledR}$, which involve minimal effort (EXW in exporting and DAP in importing) and do not require carrying out additional obligations and/or taking extra risks.

The findings indicated that legal regulations on foreign markets and geographical distance were the external factors which had the strongest influence on companies' decision-making on Incoterms ${ }^{\circledR}$. Among the internal determinants, the cost of transportation and warehousing was the factor affecting the selection of Incoterms ${ }^{\circledR}$ the most. The fact that most of companies don't consider domestic and foreign competition as a factor strongly affecting their decisions on Incoterms ${ }^{\circledR}$ may suggest that the use of Incoterms ${ }^{\circledR}$ as a strategic tool for building competitive advantage is often underestimated. Also, many traders seem to be mainly focused on cost of transportation but do not see the link between Incoterms ${ }^{\circledR}$ and terms of payment or other financial aspects of transaction.

Knowledge and understanding of Incoterms ${ }^{\circledR}$ is crucial in international trade. The selection of Incoterms $^{\circledast}$ is often considered as a difficult task because of the insufficient knowledge in this field and because the choice of appropriate Incoterms ${ }^{\circledR}$ tends to be considered as a constraint rather than as an opportunity to improve the efficiency of an international deal. Our respondents are aware of the benefits of Incoterms ${ }^{\circledR}$ in the field of enhanced transparency and clear definition of rights and obligations of the contractual parties with regard to delivery terms and thus avoiding conflicts or facilitating the settling of disputes, but do not fully appreciate their role as a strategic tool, which can increase the efficiency and cut costs across the supply chain. At the same time, the vast majority of respondents stated that there is a need of training in this field.

Our research was an attempt to fill the gap in knowledge regarding Incoterms ${ }^{\circledR}$, and the obtained results can be used both by entrepreneurs making decisions about Incoterms ${ }^{\circledR}$, who need guidance on their correct application, and by educators, which should better respond to the need to expand knowledge and skills about Incoterms ${ }^{\circledR}$, especially with respect to Incoterms ${ }^{\circledR}$ selection and its determinants, by shaping their educational offer appropriately. 
Nevertheless, this study has some limitations, which include a low response rate due to companies' reluctance to provide information, the sample dominated by large and medium companies, not taking into account the specificity of individual industries.

The further research on the use of Incoterms ${ }^{\circledR}$ in sales and purchase contracts could focus more on the sector of small and medium-sized enterprises, which is a dominant business sector in many national economies. It would be beneficial to analyze the differences in the use of this tool across countries or industries. Examining the correlation between Incoterms ${ }^{\circledR}$ selection and export performance as well as measuring the influence of Incoterms ${ }^{\circledR}$ on improving company efficiency and cutting costs across the supply chain could also prove interesting to study.

\section{REFERENCES}

Bergami, R. (2013). Managing Incoterms 2010 risks: tension with trade and banking practices. International Journal of Economics and Business Research,6(3), 324-338.

Chevalier, D. (2000).Incoterms 2000 : Tous les mécanismes. Paris: MOCl. Hors série.

Davis, J.,\& Vogt, J. (2021). Incoterms ${ }^{\circledR} 2020$ and missed opportunities for the next version. International Journal of Logistics Research and Applications.DOI: 10.1080/13675567.2021.1897974

Debattista, C. (2020). Incoterms ${ }^{\circledR}$ 2020. Introduction. Paris: International Chamber Of Commerce. Retrieved on October 25, 2021 from https://iccwbo.org/publication/incoterms-2020-introduction.

Deloitte (2020). Incoterms ${ }^{\circledR} 2020$ - The hidden champions of efficiency. Your guide to improving business performance across the entire value and supply chain. Retrieved August 2, 2021 from https://www2.deloitte.com/de/de/pages/consumer-business/articles/incoterms-2020-white-paper.html;.

Duncan, R. (1972). Characteristics of Organizational Environments and Perceived Environmental Uncertainty. Administrative Science Quarterly17(3), 313-327.

Gardner, D.L. (2012). How to Use International Trade Terms for Competitive Advantage \& Financial Gain. Los Angeles: Trade Facilitators, Inc.

Hien, N., Laporte, G., \& Roy, J. (2009). Business Environment Factors, Incoterms Selection and Export Performance. Operations and Supply Chain Management: An International Journal,2(2), 63-78.

Huuhka, H. (2019). Effective Use of Incoterms in the Case Company. Pori: Satakunta University of Applied Sciences. Degree Programme in International Trade. Retrieved August 5, 2021 fromhttps://www.theseus.fi/bitstream/handle/10024/160438/Henni_Huuhka.pdf.pdf?sequence=1\&isAllowed=y

ICC (2019). Incoterms ${ }^{\circledR}$ 2020. ICC Rules for the Use of Domestic and International Trade Terms. ICC Publication: 723E. Paris: ICC Services Publications Department.

ICC (2021). Incoterms ${ }^{\circledR}$ Rules. Retrieved October 20, 2021 fromhttps://iccwbo.org/resources-for-business/incoterms-rules.

ITA (2021). Know your Incoterms ${ }^{\circledast}$. Washington: International Trade Administration. U.S. Department of Commerce. Retrieved August 23, 2021 from https://www.trade.gov/know-your-incoterms

Malfliet, J. (2011). Incoterms 2010 and the mode of transport: how to choose the right term. Management challenges in the 21st century : transport and logistics : opportunity for Slovakia in the era of knowledge economy, Proceedings (pp. 163-179). Presented at the Management Challenges in the 21st Century: Transport and Logistics: Opportunity for Slovakia in the Era of Knowledge Economy Bratislava, Slovakia: City University of Seattle Bratislava.

Orbis (2021). Orbis database. Retrieved September, 2021 from https://www.bvdinfo.com/en-gb/our-products/data/international/orbis

Piltz, B. (2020). Incoterms ${ }^{\circledR}$ 2020. Revija Kopaoničke Škole Prirodnog Prava 1/2020, 9-28. DOI: 10.5937/RKSPP2001009P

Schaefer, T. J. (2017). Incoterms ${ }^{\circledR}$ use in buyer-seller relationships: A mixed methods study. St Louis: University of Missouri. Dissertation 692. Retrieved August 23, 2021 from https://irl.umsl.edu/cgi/viewcontent.cgi?article $=1666 \&$ context $=$ dissertation

ShipHub (2020). Reguły transport międzynarodowego. Incoterms 2020.Retrieved August 23, 2021 from https://www.shiphub.pl/incoterms

Stojanović, D.,\&lvetić, J. (2020). Possibilities of using Incoterms clauses in a country logistics performance assessment and benchmarking. Transport Policy, 98, 217-228. https://doi.org/10.1016/j.tranpol.2020.03.012 
Suraraksa, J., Amchang, C., \& Sawatwong, N. (2020). Decision-Making on Incoterms ${ }^{\circledR} 2020$ of Automotive Parts Manufacturers in Thailand. The Journal of Asian Finance, Economics and Business, 7(10), 461-470. DOI: 10.13106/JAFEB.2020.VOL7.NO10.461

Unal, T.D., \& Metin, I. (2021). Do the factors affecting Incoterms ${ }^{\circledR}$ selection differ for exporters and importers? A fuzzy analytical hierarchy process (FAHP) application. LogForum17(2), 299-309. DOI: 10.17270/J.LOG.2021.585

Wood, G., \& Aversa, F. (2019). Procurement contracts and Incoterms; How to ensure your supply contracts are not incompatible with Incoterms ${ }^{\circledR}$. Retrieved August 23, 2021 from https://www.lexology.com/library/detail.aspx?g=4d25c17b-fc34-4b7a-8154-21a6aa78aafb

Yaakub, S., Szu, L. Y., Arbak, S., \& Halim, N. A. (2018). Incoterms ${ }^{\circledR}$ selection factors and its effect on export performance. Journal of Advance Research in Business, Marketing, and Supply Chain Management, 2(1), 9-18.

\section{Authors}

The contribution share of authors is equal and amounted to $50 \%$ for each of them.

$\mathrm{AH}$ - conceptualisation, literature review, designing a questionnaire, methodology, discussion; $\mathrm{BP}$ - conceptualisation, methodology, contributing to designing questionnaire, calculations, discussion.

\section{Agnieszka Hajdukiewicz}

Assistant professor, PhD in economics. Works at the Department of International Trade, Cracow University of Economics (Poland). Her research interests focus on trade protectionism, barriers to international trade, international trade and policies in the agricultural sector, international marketing and economic diplomacy.

Correspondence to: Dr Agnieszka Hajdukiewicz, Cracow University of Economics, Department of International Trade, ul. Rakowicka 27, 31-510 Kraków, Poland, e-mail: hajdukia@uek.krakow.pl

ORCID (1) http://orcid.org/0000-0002-8249-2314

\section{Bożena Pera}

Assistant professor, PhD in economics, Works at the Department of International Trade, Cracow University of Economics (Poland). Her research interests focus on international trade, international economic integration, regional trade agreements, international trade policy and international business.

Correspondence to: Dr Bożena Pera, Cracow University of Economics, Department of International Trade, ul. Rakowicka 27, 31-510 Kraków, Poland, e-mail: perab@uek.krakow.pl

ORCID (1) http://orcid.org/0000-0003-3274-8788

\section{Acknowledgements and Financial Disclosure}

This publication is co-financed by the subsidy granted to Cracow University of Economics from the Ministry of Education and Science.

\section{Conflict of Interest}

The authors declare that the research was conducted in the absence of any commercial or financial relationships that could be construed as a potential conflict of interest.

\section{Copyright and License}

This article is published under the terms of the Creative Commons

Attribution - NoDerivs (CC BY-ND 4.0) License

http://creativecommons.org/licenses/by-nd/4.0/ 